\title{
The scientific-community interface over the fifteen-year eruptive episode of Tungurahua Volcano, Ecuador
}

\author{
Patricia A Mothes ${ }^{*}$, Hugo A Yepes, Minard L Hall, Patricio A Ramón, Alexander L Steele and Mario C Ruiz
}

\begin{abstract}
The successful handling of Tungurahua's frequent eruptions during 15 years via permanent instrumental monitoring and good community relations by the Instituto Geofísico of the Escuela Politécnica Nacional (IGEPN) is due to these factors: 1./ Instrumental monitoring of Tungurahua volcano by the IGEPN started a decade before the 1999 reactivation. In early 1999 increased background seismicity and high $\mathrm{SO}_{2}$ readings suggested that magma was stirring. 2./ The long-term participation of IGEPN scientists in both monitoring and volcanic studies has fostered an institutional memory and a knowledge base that is referential for providing early warnings and in aiding the authorities to make critical decisions in anticipation of dangerous volcanic behavior. 3./ The permanent presence of IGEPN scientists at Tungurahua's Volcano Observatory (OVT) who oversee the monitoring operations and maintain close contact with the threatened community. 4./ Participation of volunteer volcano observers from the community (vigías) who convey their observations 24 hours/ day via a pan-volcano UHF radio system.

Challenges to the operation's success include: identifying precursor geophysical signals before volcanic eruptions begin; financing OVT's operations and real-time instrumental surveillance; assuring active involvement of experienced scientists at OVT; instructing new rotating public officials in volcanic hazards and volcano crisis management, as well as working alongside them during critical moments; maintaining positive working relations with the community. Here we report on volcano monitoring and risk reduction strategies that have served the IGEPN in a semi-rural environment, where $~ 30,000$ people reside in high-risk zones. On reflection, we believe that our "bottom-up" approach has been effective and has merit. This approach developed gradually; our actions were in response to our instrumental monitoring activity of Tungurahua, providing credible information to the public and authorities and overcoming negative perceptions by the population. If there is a recipe, it is conditioned on good monitoring results and interpretation that is adequately and frequently communicated to those concerned, and over many years fostering a mutual trust among the actors. Some strategies described herein may not be pertinent at a volcano whose eruptive activity is short-lived.
\end{abstract}

Keywords: Tungurahua volcano; Early warnings before eruption; Volcano observatory; Scientific-community relations; Vulcanian eruptions; Vigías

\section{Background}

As described by Tobin and Whiteford (2002), after culmination of the 3 month-long forced evacuation of about 26,000 people in Baños and areas surrounding Tungurahua volcano in October, 1999, the affected population remained resentful and leery of scientists and their monitoring and hazard communication efforts. The local population openly blamed the volcano monitoring

\footnotetext{
* Correspondence: pmothes@igepn.edu.ec

Instituto Geofísico, Escuela Politécnica Nacional, Casilla 1701-2759, Quito, Ecuador
}

scientists for this unfortunate situation. Such circumstances made it difficult over the next several years for IGEPN volcanologists to be fully accepted in the Baños area. Herein we describe the strategies the IGEPN embraced to change a negative situation, to one that is positive.

Tungurahua volcano (Latitude $01^{\circ} 28^{\prime} \mathrm{S}$; Longitude $78^{\circ}$ $27^{\prime} \mathrm{W}$ ) is located in the southern portion of the Eastern Cordillera of the Ecuadorian Andes, $140 \mathrm{~km}$ south of Quito and $33 \mathrm{~km}$ southeast of Ambato, the capital of Tungurahua Province (Figure 1). The 5023-m-high active 


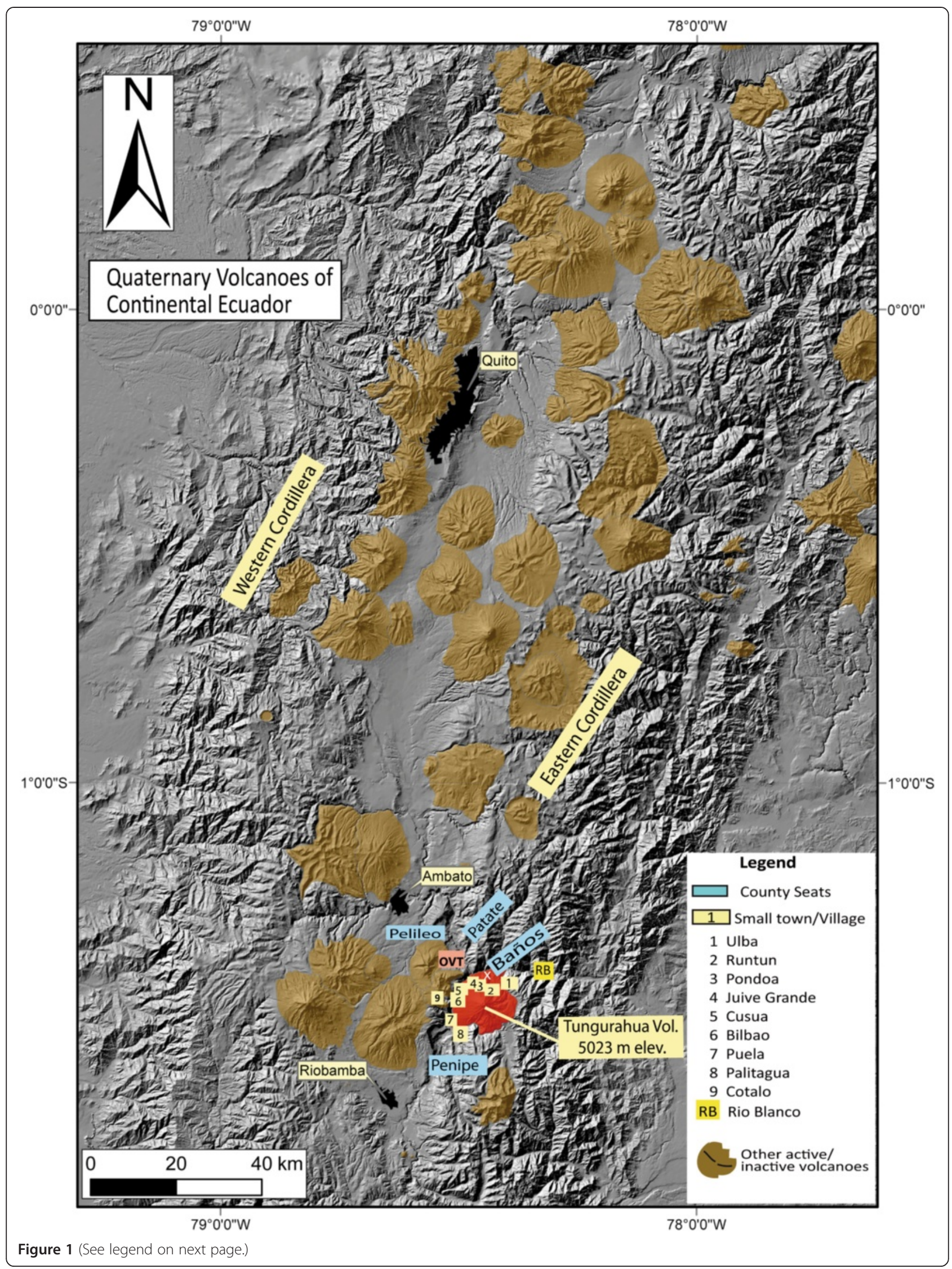


(See figure on previous page.)

Figure 1 Map of most Quaternary volcanoes of continental Ecuador. The two main cordilleras are highlighted- the Western and the Eastern, respectively. Tungurahua volcano is located near the southern end of the Eastern Cordillera. County seat cities mentioned in the text: Baños, Pelileo, Patate and Penipe are shown, as are smaller towns and villages and OVT. Modified from: Bernard, B and D. Andrade, 2012. "Volcanes Cuaternarios del Ecuador Continental". IGEPN internal publication, Quito- Ecuador.

stratovolcano is notable for its extreme relief of $3200 \mathrm{~m}$, steep sides, and frequent eruptive cycles. Its 400-m-wide crater is situated slightly NW of Tungurahua's summit with the lowest rim (at $4800 \mathrm{~m}$ ) on its NW side, favoring spillage of pyroclastic and lava flows onto the upper NW and $\mathrm{W}$ flanks, and potentially lower down into the communities of Juive Grande, Cusúa and Bilbao, among others (Figures 1 and $2 \mathrm{a}$ and $\mathrm{b}$ ).

The actual Tungurahua edifice is recent. After a catastrophic sector collapse of the previous cone some 3000 years ago, it has rebuilt itself at the same location with its current symmetrical shape (Hall et al. 1999). Important eruptive activity occurred between AD 1300 and 1700 (Le Pennec et al. 2008). Five major eruptive episodes are recognized in historical reports: 1641-46,
1773-81, 1886-88, 1916-18, and the present period. Andesitic lava flows, pyroclastic flows, ash falls, and secondary lahars characterize the volcano's activity (Hall et al. 1999). Tungurahua is a dangerous volcano that threatens the tourist town of Baños ( 20,000 residents; $\leq 50,000$ on holidays) as well as small villages located around the base of the cone (Figures 1 and 2a, b).

Since 1999 the eruptive activity of Tungurahua volcano has varied between volcano explosivity index (VEI) levels of $<1$ to 3 , generally allowing the continuance of tourism, agricultural, and other economic activities around the volcano's edifice. On-off eruptive cycles occurring every 4-12 months have helped to maintain the attention of local and regional authorities and the population at large during this drawn-out eruptive process.
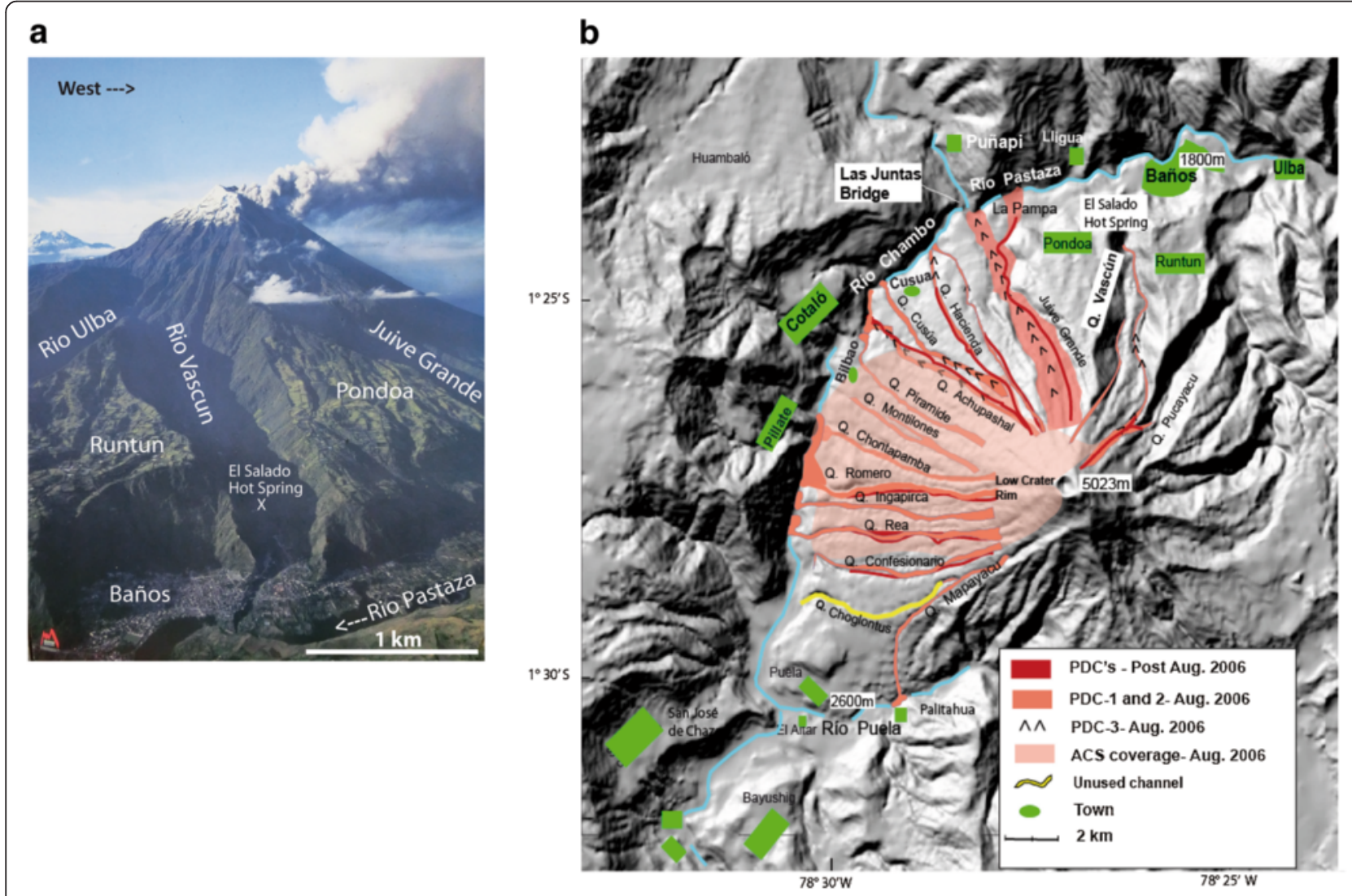

Figure 2 Tungurahua volcano, location of Baños city and other communities and paths of the 2006 pyroclastic flows. a: Modified aerial photograph of Tungurahua volcano taken before the $\mathbf{2 0 0 6}$ pyroclastic -flow forming eruptions. The tourist city of Baños is located at the northern foot of the cone, and partially on the fan of the Rio Vascún. The extreme relief between the summit and Baños is 3200 meters over a $7 \mathrm{~km}$ distance. Photo courtesy of Jorge Juan Anhalzer- Quito. b: Digital elevation map of the whole volcano showing all major quebradas on the north, west and SW flanks, pyroclastic flow paths of 2006 and post 2006, identified as pdcs in the legend, and ashcloud surge (ACS) of the same eruption, and main town and rivers. 
From 1999 and to the present, eruptive activity has varied between intermittent periods of low to moderate Strombolian-style eruptive activity to notable Vulcanian and sub-Plinian events. In the first seven years the activity was mainly characterized by Strombolian episodes with frequent but small explosions, lava fountaining, and ejection of incandescent ballistics, sub-regional to regional ash falls, and rain-generated lahars (Leonard et al. 2005). However, no pyroclastic flows were produced in this 7 year period. Later, sub-Plinian eruptions on 17 August 2006 generated sizeable pyroclastic flows $\left(40 \mathrm{Mm}^{3}\right.$, bulk volume) (Hall et al. 2013) (Figure 2b). During these eruptions and subsequently, Vulcanian-like explosive outbursts accompanied the most intense Strombolian eruptions and were characterized by powerful infrasound signals and audible booms during paroxysmal phases (Ruiz et al. 2006; Hall et al. 2013). From May 2010 to present, activity has been interspersed by Vulcanian-style eruptive outbursts of varying intensity, often producing explosions with high infrasound values as well as small-volume pyroclastic flows, some which reached the volcano's base (Figure 2b).

Since September, 1999 the IGEPN has maintained a permanently-staffed observatory (OVT) located $13 \mathrm{~km}$ NNW of the crater and at its principal office in the Escuela Politécnica Nacional, Quito, where it has operated 24 hours a day, 7 days a week. Continual monitoring of Tungurahua employs collocated seismic and infrasound instruments (short period and broadband), $\mathrm{SO}_{2}$ gas emission detection (COSPEC and DOAS) and geodetic methods (EDM, tiltmeters, GPS and occasionally InSAR). In addition, thermal imagery (airborne and ground-based) during the past 10 years has proven to be invaluable for nighttime and foggy observations. Available satellite information is also used in the visible, infrared and radar ranges for the detection of ash plumes, hot spots, and thermal anomalies, and to measure $\mathrm{SO}_{2}$ concentrations in the atmosphere and to obtain radar interferograms (InSAR). IGEPN uses twelve acoustic-flowmonitoring stations (AFM) (Hadley and LaHusen 1995) to detect and register secondary lahar activity (Figure 3). Lahars are frequently generated by the remobilization of loose volcaniclastics by rainfall on the cone's steep slopes; they are the most commonly occurring hazard and they affect the main roads that circumvent the volcano and also some infrastructure. During the 15 year eruptive episode more than 800 lahars have been registered by the AFM monitoring system, often resulting in lahar warnings issued to the public from OVT (Mothes and Vallance 2015).

\section{Methods: inputs for the IGEPN's monitoring and communication strategies}

The importance of IGEPN's local observatory, OVT

The strong onset of Tungurahua's unrest in September 1999 required that a local observatory be established.
The generous loan of a hacienda farmhouse $13 \mathrm{~km} \mathrm{NW}$ of the volcano, provided an ideal line-of-sight view of the volcano (Figure 3). The Observatorio del Volcán Tungurahua, OVT, is staffed by a senior scientist and an assistant on rotating shifts of eight days, thus satisfying the need to have a sustained local scientific presence which greatly facilitates rapid recognition of changes on the volcano and in managing developing situations, if necessary. These two individuals record visual and audible activity, foster and evaluate incoming signals from the volcano's monitoring network, provide support to national and international scientists and students conducting fieldwork on the volcano, participate in meetings at the local and provincial level, communicate with the populace at large, give interviews for radio and TV stations and to the press, and provide frequent verbal updates about the volcanic activity over the regional UHF radio system. They also perform data collection from thermal springs, gas measurements with mini-DOAS, and make observations and sampling of fresh ash and lahar deposits. Observations made by the local volcano observers, vigías, reporting to OVT over the radio system, are recorded at all hours. During the months-long intervals of relative quiescence between strong eruptive periods, activities at OVT are in a lull and the demands are lower. Generally OVT scientists can catch up on field work, academic obligations, and perform upkeep of the monitoring network around the volcano.

During the eruptive period from 1999 to early 2006, the permanent presence of IGEPN scientists at the volcano assured people that the volcano was being monitored full time. Nonetheless this volcano monitoring service wasn't exempt from risk. In 2000 several of Baños' hotel owners blamed the OVT and IGEPN scientists for lack of tourist visitation to their facilities, proclaiming that excessive information about the volcano's behavior was being shown in the media and tourists were canceling their hotel reservations in Baños. Their hostile attitudes were perhaps a lingering response to the evacuation in 16 October 1999 to January 5, 2000, when all Baños' hotels closed, thus causing a local economic crisis (Lane et al. 2003). At the most critical moment some hotel owners threatened to chase out OVT scientists with machetes and even to set the observatory on fire! Eventually the difficulties were worked out and faded with time, mostly because the OVT personal began giving weekly live interviews on a Baños radio station in which the townspeople heard updates of the volcano's status and a daily interpretation of monitoring data. Many talks were also given to communities about the nature and benefits of volcano monitoring and trends in the eruptive process; some talks were done under the auspicious of a European Community-funded DIPECHO project, which at that time was involved in ameliorating social issues in 


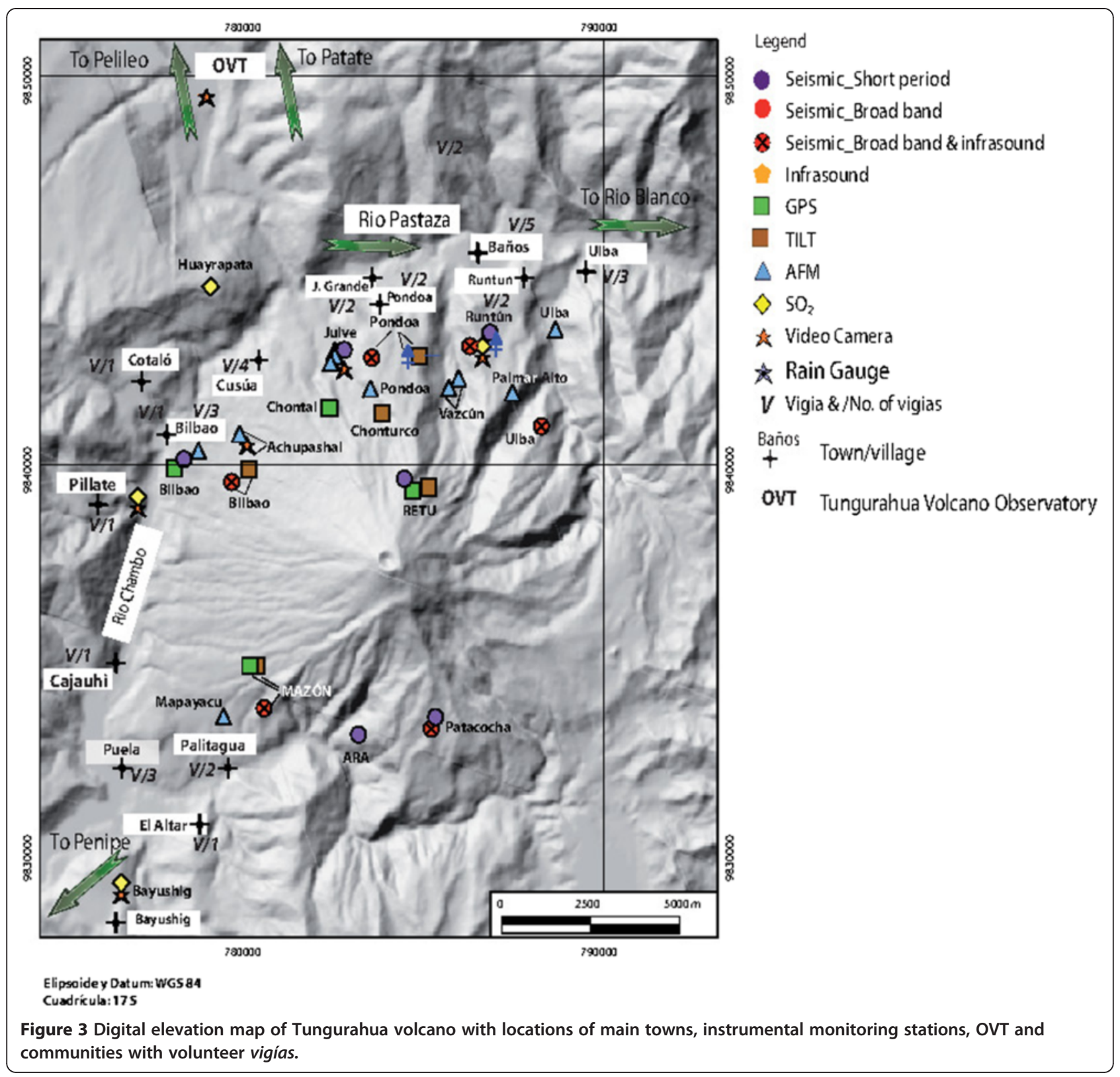

the affected areas to the west of the cone. Local people also became accustomed to the permanent presence of the IGEPN scientists in the area, eventually perceiving OVT operations and its mission as a benefit to their overall security. Meanwhile, the economic base improved around Baños and tourists again filled the hotels, even though the volcano remained active and the IGEPN continued normal reporting (Sword-Daniels et al. 2011).

Compared with the basic setup of fifteen years ago, the monitoring network in 2015 is considerably more robust. OVT relies on broad band (BB) and short period seismic networks and also infrasound sensors linked to the BB stations (Kumagai et al. 2010). Telemetered electronic tiltmeters, continuous GPS stations, continuously recording video and thermal cameras, more lahar monitors and four telemetered $\mathrm{SO}_{2}$ detection systems (DOAS) have greatly improved the IGEPN's capacity to provide better prognosis before eruptive activity's onset (Figure 3). Also, during eruptions a 25 station ashcollection network is used to evaluate rates of ash accumulation and volumes (Bernard et al. 2013).

\section{The social/political network around the volcano}

Since the onset of Tungurahua's eruptive activity the IGEPN has maintained broad working relationships with mayors, governors and other popularly-elected officials, 
as well as central government-designated public servants and civil defense personnel. Elected public servants generally serve for 4 years. Between 1999 and 2006 risk management before and during natural hazard events was carried out by the Ecuadorian Civil Defense through personal in their local, provincial and national offices. Subsequently, after 2006 the newly formed National Secretary of Risk Management (SNGR) became the main coordinating entity charged with risk mitigation in the face of floods, landslides, volcanic and seismic activity. Since early 2014, each county throughout the country is required to designate a risk management coordinator whose job is to prepare local citizens before events of adverse nature and also to coordinate mitigating actions at the county level. The SNGR of the national government interacts with the governors of each province, overseeing the coordination of activities between county and provincial officials. Overall this setup has enabled the IGEPN to provide rapid and frequent briefings to authorities concerning increases in pre-eruption signals and to help them to make critical decisions before major eruptive events. Baños did not have evacuation plans prior to the reactivation of the volcano in 1999, nor when the city and highrisk areas around the volcano were forcefully evacuated for three months starting on 16 October, 1999, at which time the Ecuadorian military handled all procedures. The forced and prolonged evacuation of 26,000 residents generated deep resentment in the affected citizens and huge economic loses. They fully blamed the IGEPN for the actions taken, even though we had not made the decisions to evacuate them or keep them away from their homes and livelihoods for 3 months (Tobin and Whiteford 2002). It took years to overcome these accusations and part of the IGEPN's response was to develop positive interactions with the local community (Leonard et al. 2005).

But evacuation plans existed and were used to evacuate Baños during the paroxysmal stage of the 17 August 2006 sub-Plinian eruption. In this instance, given the volcano's strong, overwhelming superficial manifestations, the townspeople willingly evacuated to safe zones. Subsequently, no other broad evacuations have occurred, however smaller village-specific evacuations have occurred before heightened eruptive activity in May 2010 and February, 2014. Also, in most cases when activity ramps up, members of the communities of Cusúa and Bilbao sleep in safe zones, and return in the morning to do chores.

Some officials are willing to act on pre-eruptive advisories from IGEPN scientists, while others are more reluctant to act due to the pressure from local hotel and tourist interests, again, particularly in Baños. Two cases illustrate these circumstances. Days before the 14 July 2006 eruption, the governor of Tungurahua province demanded in a written statement that the IGEPN desist from reporting about the volcano's condition, claiming that it was chasing tourism away from Baños. He proclaimed that from then on he personally would be fielding all responses to inquiries from members of the press, local and national officials, and the population at large about the volcano's activity (Figure 4). At this time daily and special reports were being prepared at the IGEPN and sent out to 560 recipients via fax and internet, and up to 10 interviews with the media were granted daily from OVT and the Quito office. The IGEPN respectfully obeyed the written order and smartly redirected telephone calls and requests for scientific information and interviews to the governor's office and personal phones, so that he could explain to all concerned the rapidly evolving state of the volcano on a $24 / 7$ basis. His readiness to take on this task quickly waned when he recognized his shortcomings to credibly answer questions about the volcano's heighten state of restlessness and in perceiving the constant and extraordinary social pressure to provide immediate and reliable scientific information. Within 24 hours, via a second written order, the governor reinstated the IGEPN's communication responsibilities, barely two days before the 14 July $2006(\mathrm{VEI}=2)$ eruption.

A month later, on the morning of the $16^{\text {th }}$ of August 2006, about 14 hours before onset of Tungurahua's largest eruption since 1918, amidst unceasing high-decibel explosions and continually felt vibrations throughout the region- due to low frequency volcanic tremor accompanying magma ascent, the principal authority of Baños was unreachable by telephone or radio at $10 \mathrm{am}$ when the IGEPN director called to advise/warn him that a large eruption was believed to be imminent and that certain areas could be overrun by pyroclastic flows. Fortunately the local civil defense chief took responsibility and made the decisions to evacuate people from several threatened villages and Baños city before the paroxysmal finale at about $00 \mathrm{H} 30$ (local time) on August $17^{\text {th }}$ (Hall et al. 2013). There were no serious casualties in Baños county, although about 60 homes were overrun and scorched by pyroclastic flows, particularly in the Juive Grande sector, where thankfully the residents had responded to the alert and were not injured. The hydroelectric facility of Agoyan (156 MW), $3 \mathrm{~km}$ downriver from Baños, also responded successfully to OVT's early warnings and their engineers carried out the company's emergency plans to close the intake tunnel to the turbines, thus avoiding damage to the turbines from severe abrasion or blockage by fresh volcanic products; they also opened the dam's floodgates to permit the flowthrough of dense materials. A few days later after a general revision and filling of the reservoir, the facility was again operating normally.

The mayors of the neighboring counties of Penipe and Pelileo with their communities of Bilbao, Puela and 


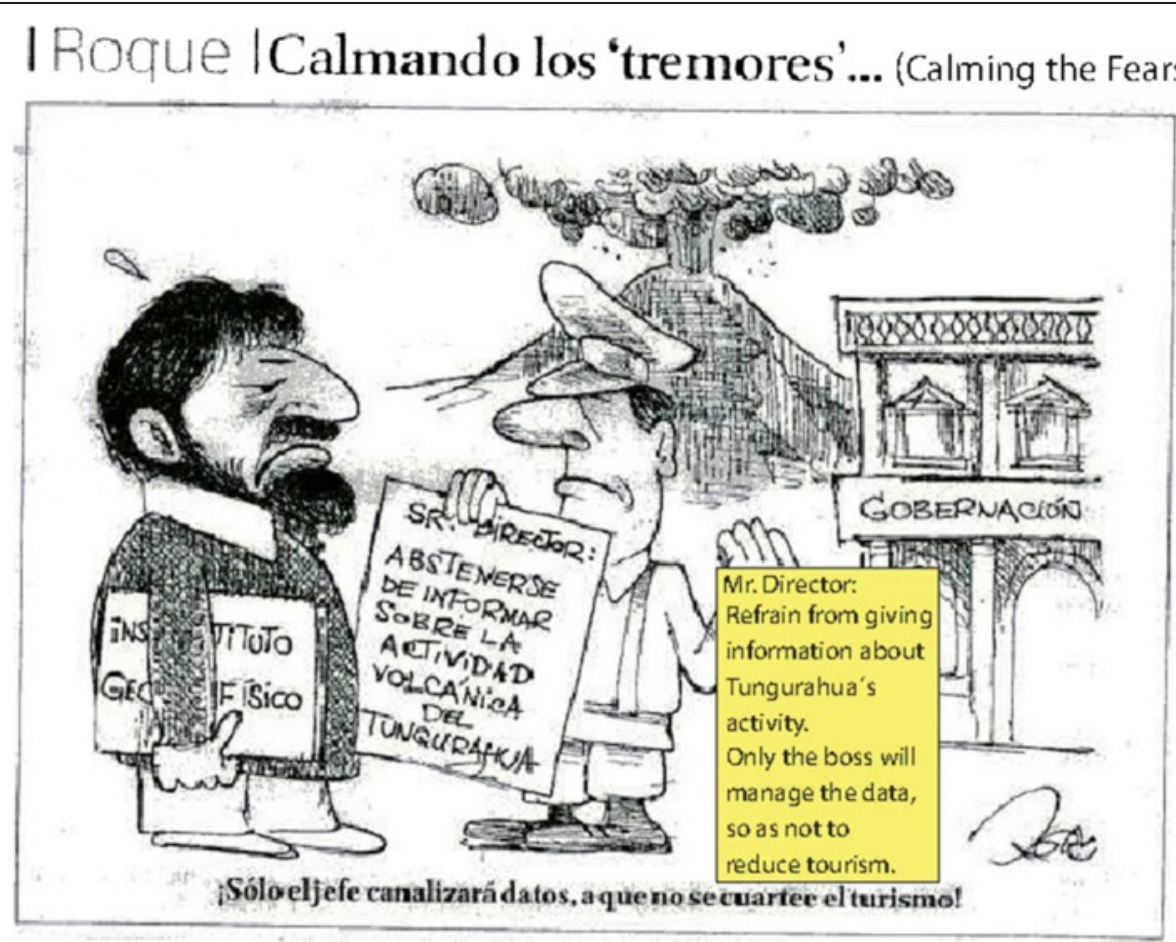

Figure 4 Cartoon modified from that which was published in Quito's "El Comercio" newspaper on 12 July, 2006 in which the director of the Instituto Geofísico is handed an order from the assistant of the Tungurahua governor. The order states that the IG director must abstain from reporting on Tungurahua's eruptive activity and that the governor will give the reports in such a way that tourism will not suffer.

Cusúa, situated around the volcano's flanks, also had their roles to play during the ramping up to the $17^{\text {th }}$ August eruption. On the evening of the $16^{\text {th }}$ the mayor of Pelileo came to OVT to give a verbal order over the radio system that residents of Cusúa and other communities of his county must evacuate. Also, the mayor of Penipe personally drove around the villages of Puela and Palitagua beseeching the citizens to evacuate before the major eruption. Unfortunately, five people didn't heed the warnings and died in Palitagua due to descending pyroclastic flows. Another short-coming in Penipe county was the lack of coverage of the panvolcano radio system, impeding a free-flow of critical information to this sector from both OVT and other actors during the crisis. Additionally, given the delays to get people motivated to leave their endangered properties, about 50 head of livestock, some grazing on the upper flanks of the volcano, perished from burns or asphyxiation. Decimeter-size ballistics fell out to $8 \mathrm{~km}$, injuring people and livestock (Arellano et al. 2008). People living to the west and southwest of the conesuch as in the Cotaló area, and who stayed inside their homes, reported huddling beneath wooden tables to avoid impacts while the ballistics crashed through their roofs.
The Vigía network and OVT- a collaborative effort

Vigía, a Spanish word for somebody who is watching and alert, describes the volunteer efforts of 25 mostly rural-based people who keep the IGEPN informed of happenings in the sector where they live and work around the volcano. As Stone et al. (2014) explained, the vigía network is a prime example of community-based monitoring that contributes to the strengthening of the whole operation. Since scientists at OVT can only observe the volcano's N and NW flanks, beginning in 2000 farmers living in other sectors of the volcano were asked by OVT staff and Civil Defense leaders to daily report the volcanic activity that they observed from their locations. This system was established with the help of the Tungurahua province Civil Defense director and his collaborators in order to further open lines of communication over all sectors of the volcano that were being affected by the eruption process. Vigías were chosen based upon their observational skills and the proximity of their homes to certain sectors of the volcano or to active lahar-frequented ravines-quebradas. They use hand-held radios that pertain to the local UHF network now operated by the SNGR. Verbal messages given by vigias are received around the clock at OVT and recorded in a logbook and corroborated with the IGEPN's 
monitoring data. The area covered by the vigía's communication network includes the southern part of the volcano in Penipe county, the western flanks of the cone that comprise part of Pelileo county, the Baños area, and the communities of Pondoa and Runtun, above Baños and Ulba (Figure 3) (Stone et al. 2014). Reporting by vigias of the descent of secondary lahars after heavy rains or snow has been very successful and has contributed to the hastening of the closure of roads before vehicles get stuck or buried in lahars. One notable lahar in February 2005 was provoked by a local electrical storm and sent a wall of water and debris into the El Salado hot spring facility located in the Vascún Quebrada, one km upslope of Baños. The vibrations made by the descending lahar caused a notable jump in the data values of the AFM station in that quebrada. This combination strongly suggesting that a lahar of substantial volume $\left(100 \mathrm{~m}^{3} / \mathrm{s}\right)$ was in transit. Thanks to the alertness of OVT scientists and their immediate communication of this dangerous situation to Baños Civil Defense authorities and the mayor, plus timely reporting by several vigías, 13 bathers were rescued before the deadly lahar inundated the thermal pools where they were relaxing (Mothes and Vallance 2015; Williams et al. 2008).

Since most vigías have lived with the volcano for many years and are dedicated to agricultural activities and attending to livestock living on the high slopes, they know well their immediate surroundings and are quick to observe anomalous behavior. Their observations offer pertinent and dependable information regarding activity on the upper slopes of the cone; for example, the type of ash fall-lithic or scoria, ash color and grain size, intensity of rainfall and its persistence, the descent of lahars and their texture or the directions taken by ash fall columns and incandescent flows. Many times the information provided by vigías closely matches patterns of seismic and infrasound data. A visual confirmation sent over the radio to OVT, for example, about the descent of a pyroclastic flow or the increase in lahar activity in one of the many quebradas draining the volcano, is a welcome compliment to the instrumental monitoring data. Nightly at $8 \mathrm{pm}$ a radio broadcast (ronda) is hosted in which each vigía reports observations concerning the volcano from his/her sector, and any other pertinent news. OVT personal record the observations of the vigias and then give an oral summation of the day's seismic and other instrumental recordings of events on the volcano and in the region.

OVT co-hosts an annual meeting/luncheon for vigías, key local officials, and OVT personal with the aim of sharing observational criteria, giving an annual scientific report on the overall trend of the volcano's activity, and maintaining collegial collaborative ties. Many vigías who live on opposite sides of the volcano might only see each other at these special events, although they all participate in the nightly radio rondas and recognize each other's voices. The annual meeting thus serves to fortify this volunteer network and keep all involved interested in participating and being attentive when an eruption period is approaching.

At the last two vigía meetings, all vigias verbally shared their observations of recent activity, but they also drew out on paper event time-lines that transpired in their sector during important eruptive periods and what actions they took to benefit their community. This activity fortified their collective memory. OVT personal keep vigías informed about scientific evaluations of the ongoing eruptive process. Special events planned for the future include discussions about strategies for fostering successful care of livestock during continual ashfall. Local university researchers will provide the know-how along with the experience of the vigias in handling their own livestock during multiple ashfall events.

Vigías also assist with the installation of IGEPN monitoring stations, cleaning ash and vegetation off solar panels, and the overall caretaking of monitoring infrastructure. At Tungurahua there have been few robberies of monitoring equipment, perhaps because people perceive that it is to their benefit that the instrumentation keeps working, but they also know that a vigía is attentive to the instrument's well-being. Through the years the vigias have become more fortified in their community leadership skills. This is because many of them have had to act responsibly during evacuations of their community when dangerous eruptive activity begins. Secondly, they are people with knowledge of how their community has dealt with the eruptive processes and they have perspective on what actions might have to be taken in the future in benefit of their community members.

\section{Results and discussion}

Challenges to providing early warnings before Vulcanianstyle eruptions

From the onset of eruptive activity in 1999 to the August eruptions in 2006 the activity can be categorized as mainly Strombolian style (Figure 5) (Arellano et al. 2008; Hidalgo et al. 2014). This means that the vent is predominantly open and high gas pressures don't accumulate, rather the activity has a rhythmic continuum of pyroclast ejections and the eruptions tend to be long-standing (Vergniolle and Mangan 2000). Typically Tungurahua's eruptive periods commence with an increased number of low-frequency earthquakes that begin to produce mild explosions with moderate infrasound characteristics. With greater conduit opening, the lava fountains jet out of the crater and continuous roiling sounds are heard. Ash falls associated with low-level lava fountaining often continues for days and covers agricultural lands to the west with black scoracious 


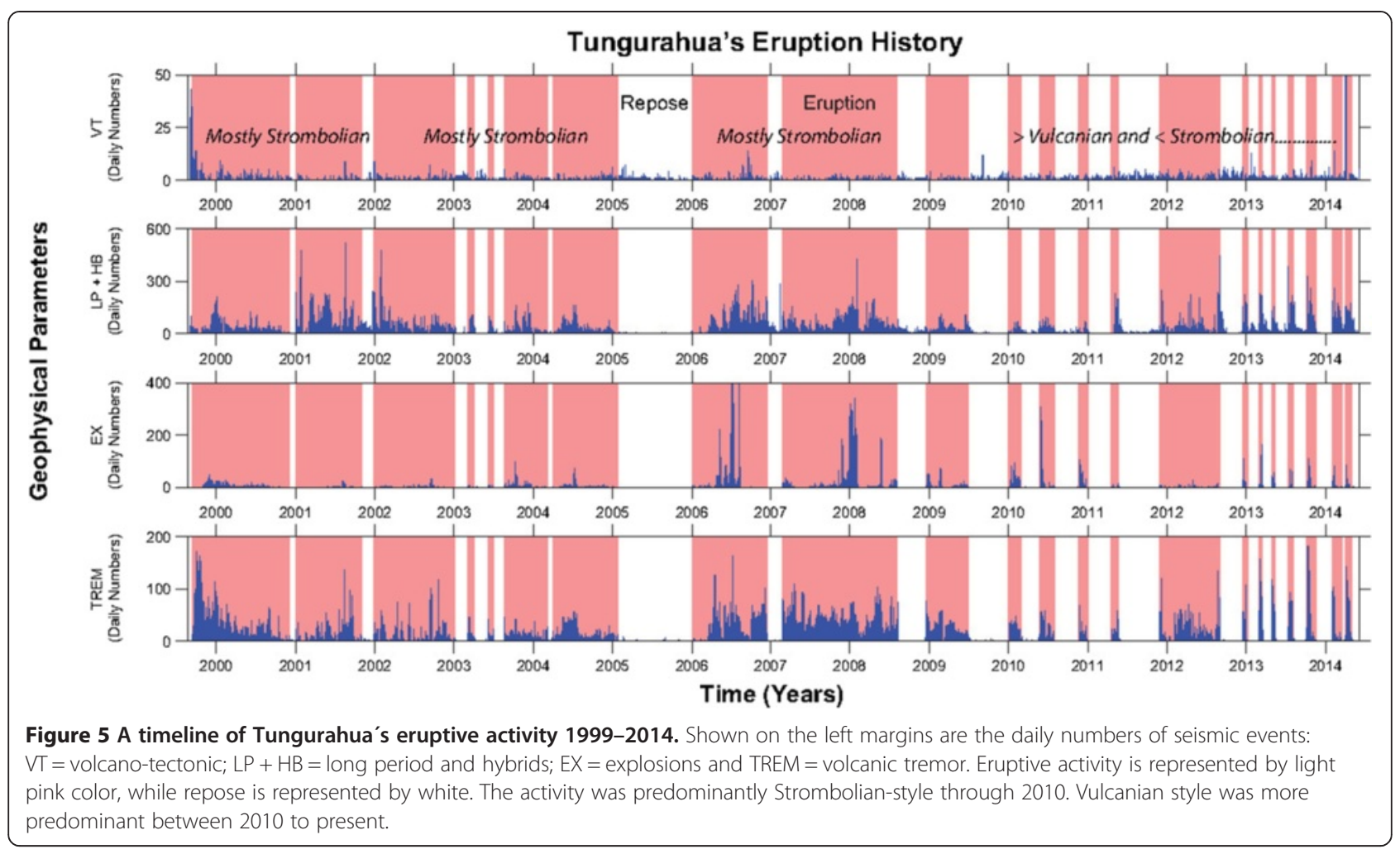

and lithic ash mantles. Notable ash fallout occurred in late 1999 and in August, 2001 (Eychenne et al. 2012). These events however did not produce pyroclastic or lava flows, and the limited ballistic trajectories kept bomb/block impacts high on the volcano's upper slopes.

In contrast, the end of the 17 August 2006 eruption was associated with the rapid ascent of a large volume of gas-rich magma (Samaniego et al. 2011) that generated pyroclastic flows that descended most quebradas on the volcano's west side, as well as the Pucayacu and Vazcún quebradas above Baños (Kelfoun et al. 2009), and overran Palitagua village on the south flank, where five residents died who had not heeded warnings to evacuate (Ramón 2010; Hall et al. 2013). A total bulk volume of almost $0.1 \mathrm{~km}^{3}$ of pyroclastic flow debris and airfall tephra was erupted (Hall et al. 2013). The last phase (Phase III) of the eruption had large Vulcanian-like outbursts and was notably more energetic than the earlier phases of eruptive activity (Figure 6) (Arellano and Hall 2007). The eruptive column rose $17 \mathrm{~km}$ above the volcano's summit (Steffke et al. 2010). Following the mid2006 eruptions and continuing through April 2010, Strombolian-style eruptions occurred about every six months and lasted about six weeks; subsequently the volcano settled into repose.

Starting on 28 May 2010, however, another large Vulcanian-style eruption began. Its rapid onset, limited open-vent eruptive activity prior to the main explosion, its loud audible characteristics, and the threat of pyroclastic flows and a broader ballistic distribution, made this event and subsequent Vulcanian events truly dangerous to local residents. Since the May 2010 event, six other Vulcanian-style eruptive episodes have occurred and have been interspersed with Strombolian-style activity (Table 1 and Figure 5). In general the Vulcanian-style eruptions are small to moderate-size, discrete explosive outbursts that last seconds to minutes. Nonetheless, the Vulcanian explosion recorded on 14 July 2013, had the highest seismic or acoustic energies ever recorded at Tungurahua (Table 1). A Vulcanian explosion occurs when an accumulation of magmatic gases beneath a sealed conduit plug or dome attains high overpressures that cause brittle failure of the impermeable plug and produces a discrete eruption in which the gases, clasts, and juvenile products are violently released (Morrissey and Mastin 2000; Clark 2013). After the initial conduit opening, Plinian and sub-Plinian eruptions with juvenile products may follow. Vulcanian eruptions typically emit volumes $<0.1 \mathrm{~km}^{3}$ of dense rock equivalent (DRE) (Morrissey and Mastin 2000).

Nonetheless, Strombolian-style activity briefly returned to Tungurahua in 2011 and the eruptions produced approximately $3.2 \mathrm{Mm}^{3}$ of magma (DRE), of which about $3.0 \mathrm{Mm}^{3}$ was new magma, as interpreted from deformation patterns at the highest tilt stations (Ruiz et al. 2012).

In most cases Vulcanian explosive events at Tungurahua were preceded by a marked brief increase in LP 


\section{Seismic Amplitude and Energy of Outburst Events; Averaged Values of Available Stations, 16-17 August, 2006}

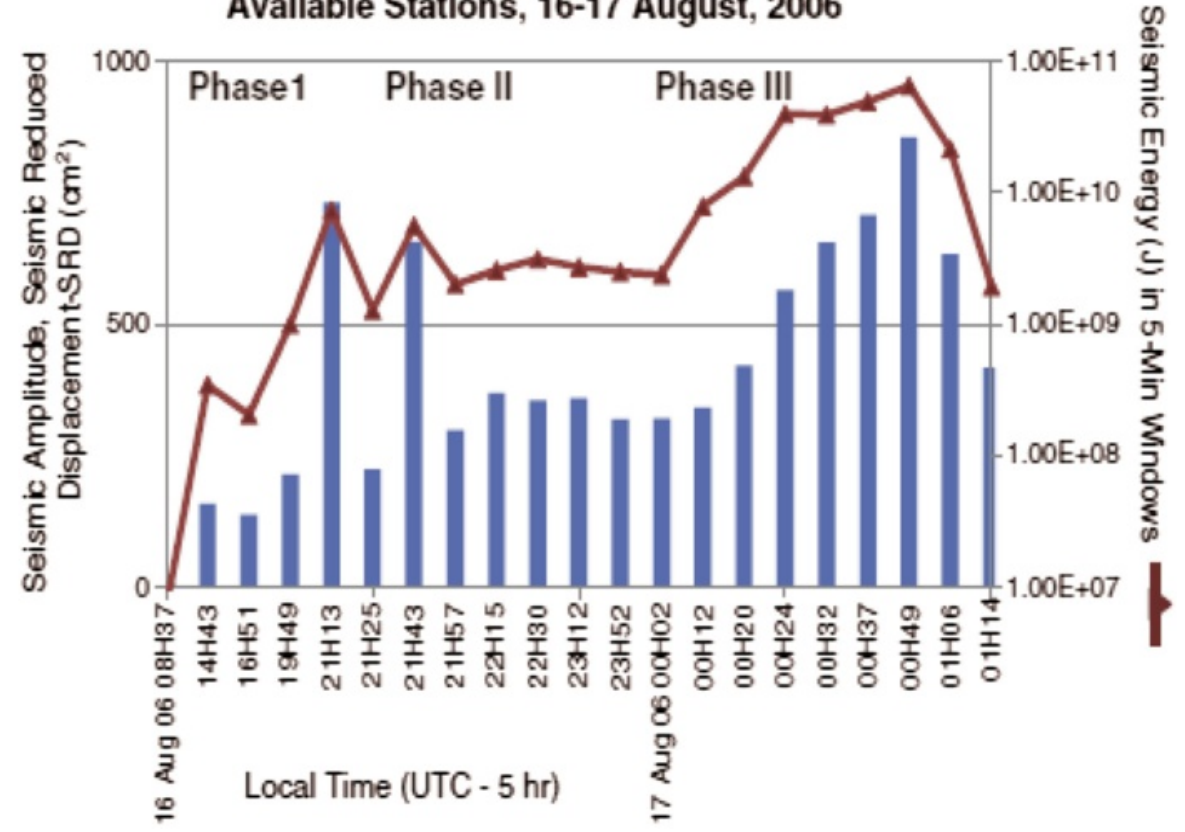

Figure 6 Graph which represents the seismic amplitude and energy of seismic outbursts (explosions) related to the eruptive sequence of 16-17 August, 2006. Note the abrupt increase of energy in Phase III during the last hour of the paroxysmal eruption when the high energies, column height and discharges were sub-Plinian.

seismic events-a swarm typically occurs a few days to several hours prior to the eruption. Other precursors include strong deformation signals registered by electronic tiltmeters several weeks prior to the eruption, especially at the station closest to the conduit (RETU) (Figure 3), and a decrease in the $\mathrm{SO}_{2}$ values registered by the DOAS instrumentation.

\section{Early warning given before major Vulcanian eruption on 1 February 2014}

Early warnings before Vulcanian eruptions are often hard to provide because of the sudden onset of this style of eruption and the subtleness of precursors (Gottsman et al. 2011). Nonetheless, there is a growing literature that reports on important ground deformation before such eruptions (Iguchi et al. 2008; Yamazaki et al. 2013).

Before Tungurahua's Vulcanian eruption of 1 February 2014, the geophysical data patterns suggested that an eruption was imminent. Although seismic signals during the previous week had been relatively minor, a strong inflationary pattern registered by the electronic tiltmeter station at $4000 \mathrm{~m}$ elevation implied that internal pressures were building beneath a rocky plug in the volcano's conduit (Figure 7). A marked shift in seismicity was observed 36 hours prior to the disruption of the conduit's plug by the three principal explosions of the 1 February 2014 eruption. A swarm of long-period seismic events and continual high-amplitude tremor heralded the run- away energy release that took place in this event (Figure 8). The 36 hr-long window of restlessness prior to the main eruption permitted the IGEPN to prepare special advisories that "a major eruption would likely occur in a short time frame (hours to days)" for the local, provincial and national authorities and the local populace. The internet, social media, phone calls, the vigía radio system, and reports on radio and television were all used to get the message out. Use of the UHF radio system at OVT was also fundamental to insure immediate updates of the ongoing activity. As the seismic swarms became more continuous and seismic and acoustic energy levels rose, another formal verbal report was issued by OVT scientists over the vigía radio system that an eruption was imminent two hours before the eruption. Accordingly, SNGR personal and the vigias advised people in their villages via loud speakers of the severity of the situation and most residents opted to self-evacuate. Military trucks and SNGR personal helped with the mobilization. Many of the farmers living on the threatened western slopes of the volcano have optional government-built housing at La Paz (a barrio of Pelileo) and Rio Blanco (east of Baños) and in Penipe town, where they and their families can spend the night. Each morning they return home and assess the damage to their property and crops, if any, and tend to livestock, which may be still grazing in the high hazard zone. 
Table 1 Registry of Vulcanian-style eruptions of Tungurahua volcano and their characteristics

\begin{tabular}{|c|c|c|c|c|c|}
\hline No & $\begin{array}{l}\text { Date/Time } \\
\text { (UTC) }\end{array}$ & $\begin{array}{l}\text { Seismic and Audible } \\
\text { Characteristics Of Vulcanian } \\
\text { Explosions }\end{array}$ & Pf's and channels used & Hrs. of Advance Warning & Comments \\
\hline \multirow[t]{3}{*}{1} & \multirow[t]{3}{*}{$\begin{array}{l}28-05-2010 \\
11: 13\end{array}$} & $\begin{array}{l}\text { Huge Explosion; N-shaped infrasound } \\
\text { (IS) waveform. High seismic to acoustic } \\
\text { ratio (low VASR). }\end{array}$ & \multirow[t]{3}{*}{ Yes, Achupashal } & \multirow[t]{3}{*}{ None } & \multirow{3}{*}{$\begin{array}{l}\text { Occurred after approximately } \\
3 \text { months of repose. It was the } \\
\text { uncorking of the volcanic system } \\
\text { after some period of pressure } \\
\text { build up }\end{array}$} \\
\hline & & $\begin{array}{l}6.91 E+08=\text { Average Seismic Energy } \\
\text { (Joules)* }\end{array}$ & & & \\
\hline & & $\begin{array}{l}1.04 E+10=\text { Average Acoustic Energy } \\
\text { (Joules)* }\end{array}$ & & & \\
\hline \multirow[t]{3}{*}{2} & \multirow[t]{3}{*}{$\begin{array}{l}21-08-2012 ; \\
15: 52\end{array}$} & $\begin{array}{l}\text { Explosion; Sharp N-shaped IS signals } \\
\text { are not consistent across the } \\
\text { network }\end{array}$ & \multirow[t]{3}{*}{ No } & \multirow[t]{3}{*}{$?$} & \multirow{3}{*}{$\begin{array}{l}\text { Occurred during a peak period in } \\
\text { volcanic activity (one of the peak } \\
\text { days of the eruptive phase), after } \\
\text { a building of activity during the } \\
\text { preceding days. }\end{array}$} \\
\hline & & $\begin{array}{l}2.85 E+08=\text { Average Seismic Energy } \\
\text { (Joules) }\end{array}$ & & & \\
\hline & & $\begin{array}{l}9.36 \mathrm{E}+10=\text { Average Acoustic Energy } \\
\text { (Joules) }\end{array}$ & & & \\
\hline \multirow[t]{3}{*}{3} & \multirow[t]{3}{*}{$\begin{array}{l}14-12-2012 ; \\
19: 36\end{array}$} & $\begin{array}{l}\text { Huge Explosion; Sharp N-shaped IS } \\
\text { signals. Compressional first seismic } \\
\text { motions. }\end{array}$ & \multirow[t]{3}{*}{ Yes, Mapayacu- SW flank. } & \multirow[t]{3}{*}{$\begin{array}{l}6 \mathrm{hr} . \text { OVT staff recognized } \\
\text { jump in activity. }\end{array}$} & \multirow{3}{*}{$\begin{array}{l}\text { Most of the energy of main } \\
\text { event was released within the } \\
\text { first } 1 \text { seconds and nearly all } \\
\text { energy in the first } 5 \text { seconds. }\end{array}$} \\
\hline & & $\begin{array}{l}1.33 E+08=\text { Average Seismic Energy } \\
\text { (Joules) }\end{array}$ & & & \\
\hline & & $\begin{array}{l}5.17 E+10=\text { Average Acoustic Energy } \\
\text { (Joules) }\end{array}$ & & & \\
\hline \multirow[t]{3}{*}{4} & \multirow[t]{3}{*}{$\begin{array}{l}16-12-2012 ; \\
10: 53\end{array}$} & $\begin{array}{l}\text { Moderate Explosion; Emergent } \\
\text { compressional seismic onset. Small, } \\
\text { P-wave - not particularly clear. }\end{array}$ & \multirow[t]{3}{*}{ No } & \multirow[t]{3}{*}{ None } & \multirow{3}{*}{$\begin{array}{l}\text { Similar to activity on the 28th } \\
\text { May } 2010 \text {. The first explosion of } \\
\text { this new phase of activity } \\
\text { recorded on the } 14 \text { December } \\
2012 \text { had partially opened the } \\
\text { conduit and vent. }\end{array}$} \\
\hline & & $\begin{array}{l}7.09 E+08=\text { Average Seismic Energy } \\
\text { (Joules) }\end{array}$ & & & \\
\hline & & $\begin{array}{l}4.79 E+10=\text { Average Acoustic Energy } \\
\text { (Joules) }\end{array}$ & & & \\
\hline \multirow[t]{3}{*}{5} & $\begin{array}{l}\text { 14-07-2013; } \\
11: 46\end{array}$ & $\begin{array}{l}\text { Huge Explosion, very strong shock } \\
\text { wave. Waveform structure is not of } \\
\text { an expected and simple 'N-shape' } \\
\text { despite shockwave presence, but } \\
\text { instead comprises a more complex } \\
\text { sequence. }\end{array}$ & \multirow[t]{3}{*}{$\begin{array}{l}\text { Yes. Achupashal and others } \\
\text { to the south; pf's arrived } \\
\text { to Chambo river. }\end{array}$} & \multirow[t]{3}{*}{ Yes, $1 \mathrm{Hr}$. } & \multirow[t]{3}{*}{$\begin{array}{l}\text { This was the largest discrete } \\
\text { explosion recorded at Tungurahua } \\
\text { since BB seismic and infrasound } \\
\text { monitoring began in July } 2006 \text {. }\end{array}$} \\
\hline & & $\begin{array}{l}1.93 E+09=\text { Average Seismic Energy } \\
\text { (Joules) }\end{array}$ & & & \\
\hline & & $\begin{array}{l}3.20 E+11=\text { Average Acoustic Energy } \\
\text { (Joules) }\end{array}$ & & & \\
\hline \multirow[t]{3}{*}{6} & \multirow{3}{*}{$\begin{array}{l}18-10-2013 ; \\
14: 26\end{array}$} & Moderate explosion. & \multirow[t]{3}{*}{ Yes, Achupashal Alto. } & \multirow{3}{*}{$\begin{array}{l}\text { Yes, volcano was already } \\
\text { erupting. }\end{array}$} & \multirow{3}{*}{$\begin{array}{l}\text { Very clear, N-shaped IS signal. } \\
\text { Impulsive compressional onset. } \\
\text { Coda up to } \sim 50 \text { seconds. Most } \\
\text { energy at }<5 \mathrm{~Hz} \text {. }\end{array}$} \\
\hline & & $\begin{array}{l}1.91 E+08=\text { Average Seismic Energy } \\
\text { (Joules) }\end{array}$ & & & \\
\hline & & $\begin{array}{l}2.60 E+10=\text { Average Acoustic Energy } \\
\text { (Joules) }\end{array}$ & & & \\
\hline \multirow[t]{3}{*}{7} & \multirow{3}{*}{$\begin{array}{l}01-02-2014 ; \\
22: 39\end{array}$} & Strong explosion. & \multirow{3}{*}{$\begin{array}{l}\text { Yes, Juive Grande and SW } \\
\text { quebradas }\end{array}$} & \multirow[t]{3}{*}{36 hrs } & \multirow{3}{*}{$\begin{array}{l}\text { Three distinct explosions at } \\
22 \text { h11; } 22 \text { h31 and } 222 \text { h39, the } \\
\text { last opened the system and was } \\
\text { followed by descent of pf's. }\end{array}$} \\
\hline & & $\begin{array}{l}2.05 E+08=\text { Average Seismic Energy } \\
\text { (Joules) }\end{array}$ & & & \\
\hline & & $\begin{array}{l}3.40 E+10=\text { Average Acoustic Energy } \\
\text { (Joules) }\end{array}$ & & & \\
\hline
\end{tabular}

*Mean seismic and acoustic values are calculated from 4 collocated broadband and acoustic sensors (Alex Steele_IGEPN, pers. Comm. 2014).

Due to the presumed high gas pressures and accumulated magma beneath the conduit plugs, the last three Vulcanian events (Table 1) produced pyroclastic flows which sped relentlessly down quebradas, arriving to the surrounding river channels 10 minutes after the main explosion (Figure 2b). Given the dynamics of the Vulcanian-style eruptions, early warnings based on geophysical parameters and conveyed over a reliable radio 


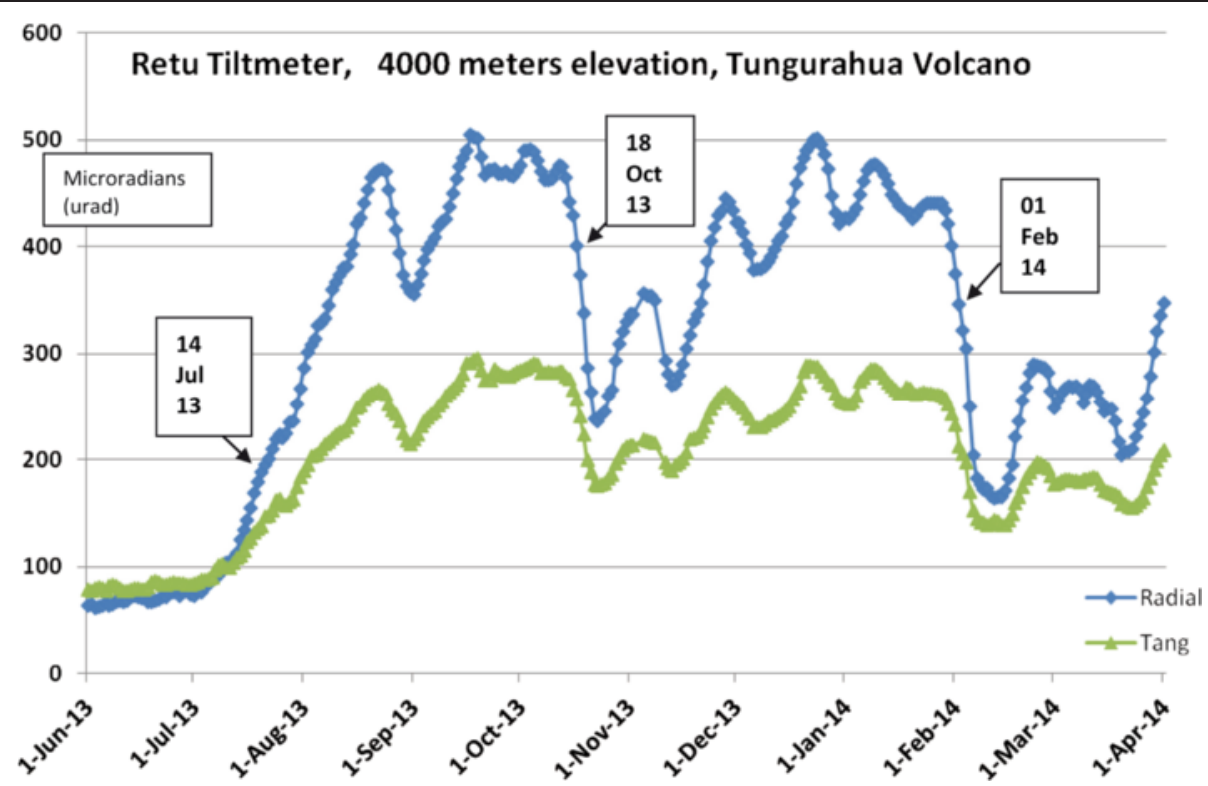

Figure 7 Plots of tiltmeter data from the electronic tilt station, Retu, located on the NW flank of Tungurahua at 4000 meters elevation. The pattern of a pronounced inflationary trend than followed by a strong downgoing "deflationary" pattern of tilt on the radial axis has been a guide for IGEPN scientists to be alert for onset of Vulcanian eruptions. Dates in boxes are onset of main Vulcanian eruptions.

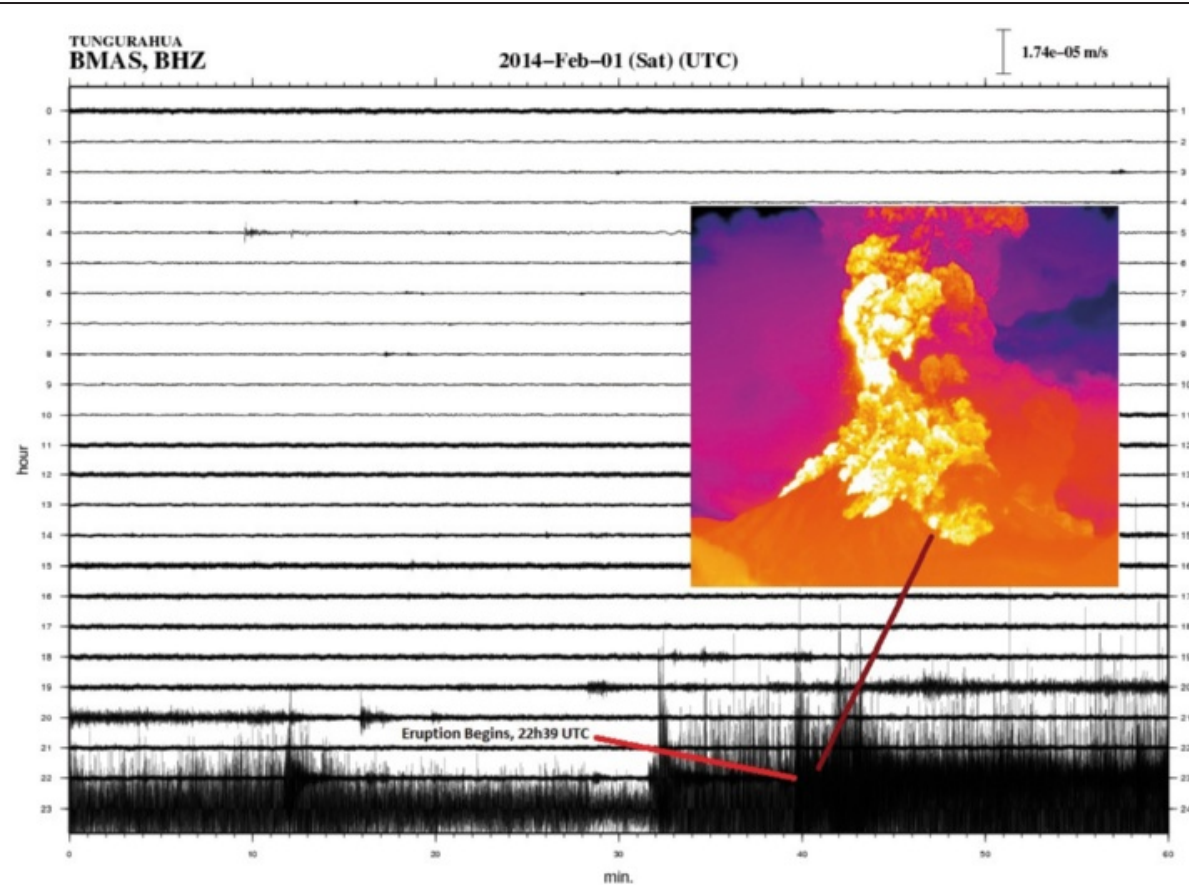

Figure 8 Seismic trace for vertical component of the BMAS broadband seismic station at Tungurahua. Note the long quiet period from 00 h00 to 11 h00, after which wide-amplitude tremor starts. The 22 h39 Vulcanian-style eruption was preceded by two smaller explosions. After the $22 \mathrm{~h} 39$ explosion pyroclastic flows were emitted and are shown in the inset of the thermal imagery photo of the NW flank of Tungurahua. Photo was taken at $22 \mathrm{H} 40$ from OVT and is courtesy of Sylvia Vallejo-IGEPN. 
system are essential for the well-being of the local population who persist living on the volcano's flanks and also those who are transiting on main thoroughfares around the volcano. Since we have identified some of the precursor geophysical parameters that may be displayed before future major Vulcanian events at Tungurahua, the IGEPN hopefully can continue to provide timely early warnings before new eruption onsets.

After fifteen years of on and off eruptions, Tungurahua has produced both Strombolian-style and Vulcanian eruptive outbursts and a varied amount of ash and eruptive products. Estimates of the amount of volcanic material expulsed up to March 2014 is based on the following data with the respective references: 1999 to July $2001=$ $14 \mathrm{Mm}^{3}$ (Wright et al. 2012); August, $2001=4 \mathrm{Mm}^{3}$ (Le Pennec et al. 2011); Late 2001-December, $2005=5 \mathrm{Mm}^{3}$ (Wright et al. 2012); August, $2006=100 \mathrm{Mm}^{3}$ (Hall et al. 2013; Eychenne et al. 2012); 2007 unknown; February, $2008=1.5 \mathrm{Mm}^{3}$ (Biggs et al. 2010); December, 2008November, $2012=20 \mathrm{Mm}^{3}$ (G. Ruiz and J. Bustillos, Pers. Comm); December, $2012=0.5 \mathrm{Mm}^{3}$ and March, $2013=$ $0.2 \mathrm{Mm}^{3}$ (Bernard et al. 2013). Since July 2013 to present at least $8 \mathrm{Mm} 3$ were expulsed in the form of pyroclastic flows (M. Hall and S. Vallejo, Comm. Pers.). A total reported bulk volume is approximately $153 \mathrm{Mm}^{3}$ of combined ashfall, lava and pyroclastic flows.

The sporadic nature of the eruptive activity and its relative predictability are important factors giving residents the confidence to keep living around the volcano. Most citizens have continued to maintain their homes and livelihoods, and that despite the explosive activity, crop yields are moderately good, some even bountiful, due to the frequent dressing of fine andesitic ash, which is quickly tilled into the soil to readily facilitate nutrient uptake by crops. Tourists travel to Baños to be close to the volcano, especially flocking to the city during the most spectacular and persistent Strombolian activity, viewing the volcano from safe hilltop perches. The city government promotes safe visitation to the volcano for local and international tourists.

Since the display of outright resentment by the population to the IGEPN monitoring scientists after the 1999-forced evacuations, the managerial aberrations that occurred in 2006 and especially after the large eruptions that same year spilled pyroclastic flows down three flanks and modified local topography, there was little doubt in people's minds that the volcano truly had the eruptive power to affect their lives and livelihoods. Until they experienced the 2006 eruptive events, residents whose grandparents had related to them the hardships they had faced following the yet bigger 1918 Tungurahua eruption, had been skeptical that the actual eruption would personally affect them or their families. Farmers still living persistently on Tungurahua's SW flanks relate that their relatives in 1918 escaped the harshness of that eruptive episode by migrating to the piedmont zone at the foot of the Western Cordillera, about $80 \mathrm{~km} \mathrm{SW}$ of Penipe, to start a new life.

Local people also developed greater respect for the IGEPN scientists, as OVT had given two successful early warnings before the July and August, 2006 eruptive episodes, and also for the recent Vulcanian-style eruptions of 2013 and that of 01 February, 2014. Good working relations with the provincial and local officials and the population-at-large around Baños, Pelileo and Penipe have typified the post-2006 eruptive period. While nobody knows what the final outcome will be at Tungurahua, if the eruption were to end now, the eruptive phase of 1999-2014 will have been more benevolent than the 1916-1918 eruptive events, whose incandescent products produced broader flow paths which were experienced and reported by deceased ancestors of families who still live around the volcano. Stratigraphy also shows us that previous historical eruptions produced larger volume ash falls and broader-reaching pyroclastic flows. For example, villages on the west flank were overrun by pyroclastic flows during earlier historical eruptions as was the western perimeter of Baños and Ulba (Le Pennec et al. 2008). The 1773 eruption brought a scoria bomb-rich pyroclastic flow into Baños center (Mothes et al. 2004).

\section{Conclusions}

The founding of OVT on a local hacienda outside of Baños gave IGEPN scientists an opportunity to experience and monitor closely the evolution of eruptive activity and to issue early warnings to authorities and the populations living in high-risk zones. OVT has also benifitted from the implementation of a wide range of modern monitoring techniques that aide scientists in the interpretation of changing conditions in the volcano, and thus provides a means for giving early warnings. The persistent local presence at OVT has helped the IGEPN to have a close evaluation of evolving eruptive activity and be in close and immediate contact with local authorities and the public. Some IGEPN scientists have been serving regular monitoring shifts at OVT since inception of the observatory and are well recognized and trusted in the community. Trust is an earned attribute which is very important during volcanic crises, because people may feel that they are putting their lives in a scientist's hands (Haynes et al. 2008). This long association with monitoring at OVT has helped to create a collective "institutional memory" within the IGEPN and have fostered a well-founded knowledge of the volcano's behavior. This understanding has facilitated the induction of young scientists into OVT monitoring activities. Young scientists, who begin as students working on a thesis, are trained at OVT over a period of months, thus 
learning the "modus operandi". They learn the volcano's geography, become acquainted with the local actors, but foremost they must learn the geophysical signs given by the volcano and the possible significance of these signals.

Personal interaction by OVT monitoring scientists with local people and vigías has helped cement relations and establish trust. The vigias are an important link between the monitoring scientists and the communities where individual vigías live. The continued real-time 24/ 7 monitoring done by the IGEPN has given people living around the volcano a greater level of security. The population has come to rely on receiving timely early warnings before eruption, and they believe that IGEPN monitoring scientists are keeping a constant eye on the volcano's pulse and trends. The vigía network and radio system also promotes the interchange of critical observations which keeps community members informed as well as giving visual and audible observations to OVT scientists.

In this contribution we reported a clear shift over 15 years, from negative to eventually positive in the public's perception of volcano monitoring and early warnings given by the IGEPN. Various circumstances played a role in this transformation, but the foremost contribution was maintaining a local observatory, staffed by scientists from a national university, the gradual insertion by various means into the local context and the scientific-community linkage that is effectively established through collaboration with vigias, being present to meet often with concerned people and officials, and to give orienting talks and debriefings on volcanic activity. Essentially the IGEPN, consciously or not, has carried out volcano monitoring and risk reduction with a "bottom-up" approach. This approach takes more time to implement compared to a topdown approach, where the people are forced to evacuate or stay out of a zone through enforcement by military or police, and perhaps where monitoring scientists have little contact with the public. Developing trust between local people, authorities and scientists is mutually beneficial, especially when the mission is long. Insertion into the local fabric is gradual and may take years if there is lingering resentment by the local population, and relies on key players at observatories who are credible, recognized and trusted. We believe that the public wants to know and hopefully trust the scientists who are providing critical information about possible impacts on their lives in decisive moments, ie, the decision to evacuate or not, being one of them.

As has been pointed out, overall moderate levels of eruptive activity of Tungurahua volcano, combined with the instrumental and human-based monitoring and warning system that is in place, has allowed local people to continue living in high risk areas. Their willingness to continue inhabiting some high risk zones is doubtless due to their connection to their land, their economic investments, the lack of another home, the custom volcano monitoring provided by OVT and for some, the ability to stay in touch by communicating over the UHF radio system. Given the powerful eruptions that occurred in 2006 and later, local residents probably realize the possibility that a surprise large pyroclastic flow could travel far down the slopes and quebradas during rapid-onset Vulcanianstyle eruptions, potentially affecting life and property. If, in the future large and multiple pyroclastic flows occur with a lead time of only minutes, not all the people who could be affected may receive an adequate warning that permits evacuation. This is because the people at highest risk, especially those living on the NW flanks, are served by evacuation routes that are cut by quebradas that may transport descending pyroclastic flows. Such a worst-case scenario, if it were to play out, could present severe complications for both the IGEPN and the SNGR and perhaps terminate inhabitation of families on the volcano's immediate flanks.

Nonetheless, after 15 years, thus far the VEI $=3$ or smaller eruptions have not surpassed the resilience of communities or of OVT scientists to adequately respond or recover from an eruption. OVT scientists continue living in this environment, communicating often with the local population via several media, including having frequent personal contact- essential actions which fortify the scientific-community interface in the area. Foremost, OVT scientists have the paramount responsibility of fingerprinting geophysical trends of Tungurahua's activity and providing early warnings before heightened eruptive activity.

Finally we must honor Tungurahua, for unlike most volcanoes that erupt in hours or days of their awakening, then resume dormancy, Tungurahua has given us 15 years of study and practice in which to improve our response and reaction and has taught us many lessons.

\section{Competing interests}

The authors declare that they have no competing interests.

\section{Authors' contributions}

PM developed the concept of the paper, wrote the draft and carried out the modifications. HY, PH and PR revised the manuscript and participated in discussions about the content. AS prepared data on Vulcanian explosions and read the text and made comments. MR discussed with all authors hazard mitigation strategies and improvements to monitoring during crises. All authors read and approved the final manuscript.

\section{Acknowledgments}

We are thankful for the Instrumentation upgrades that have been achieved in collaboration with JICA, USAID, USGS, SouthCom, UNAVCO, NOVAC, the SNGR, Proyecto BID (Early Warning System), the Ecuadorian NSF (SENESCYT) and SENPLADES. Cooperation with French IRD scientists has provided high-quality modeling of PDCs. We also extend gratitude to the Chavez Family who loans us their hacienda house for OVT operations. The DIPECHO Project helped in improving community relations and contributing to the concept of forming the Vigía group. Interactions with the STREVA project have provided stimulating conversations concerning resilience of local populations and volcano observatories. We extend thanks to the EPN for continuing support and the staff of the IGEPN. We recognize the commitment of the 25 vigias who provide invaluable observations during eruptive activity at Tungurahua. A USAID-OFDA project 
also helped to strengthen the vigía network in 2013. We are grateful to the three reviewers whose suggestions improved the manuscript.

Received: 5 August 2014 Accepted: 26 January 2015 Published online: 25 February 2015

\section{References}

Arellano S, Hall M (2007) Velocidades de emisión de bombas expulsados por el volcán Tungurahua el 16-17 de agosto de 2006. 6ta Memorias Jorn. Cien. Tierra, Esc Poli Nac, Quito, pp. 185-188

Arellano S, Hall M, Samaniego P, Le Pennec JL, Ruiz A, Molina I, Yepes H (2008) Degassing patterns of Tungurahua volcano (Ecuador) during the 1999-2006 eruptive period, inferred from remote spectroscopic measurements of $\mathrm{SO} 2$ emissions. J Volcano Geotherm Res 176:151-162

Bernard B, Bustillos J, Wade B, Hidalgo S (2013) Influence of the wind direction variability on the quantification of tephra fallouts: December 2013 and March 2013 Tungurahua eruptions. Avances 5(1):A14-A21, Quito, Ecuador

Biggs J, Mothes P, Ruiz M, Baker S, Amelung F, Dixon T, Hong S-H (2010) Stratovolcano growth by co-eruptive intrusion: the 2008 eruption of Tungurahua Ecuador. Geophys Res Lett 37:L05304, doi:10.1029/2009GL041644, 2010a

Clark AB (2013) Unsteady explosive activity: Vulcanian eruptions. In: Fagents SA, Tracy KP G, Rosaly MC L (eds) Modeling Volcanic Processes: The Physics and Mathematics of Volcanism. Cambridge University Press, England, pp 129-152

Eychenne J, Le Pennec J-L, Troncoso L, Gouhier M, Nedelec J-M (2012) Causes and consequences of bimodal grain-size distribution of tephra fall deposited during the August 2006 Tungurahua eruption (Ecuador). Bull Volcanol doi:10.1007/s00445-011-0517-5

Gottsman J, Angelis D, Fournier N, Van Camp M, Sacks S, Linde A, Ripepe M (2011) On the geophysical fingerprint of Vulcanian explosions. Earth Planetary Sci Lett 306:98-104, doi:10.1016/j.epsl.2011.03.035

Hadley KC, LaHusen RG (1995) Technical manual for the experimental acoustic flow monitor. US Geologic Surv Open File Rep 25:95-114

Hall M, Robin C, Beate B, Mothes P, Monzier M (1999) Tungurahua Volcano, Ecuador: structure, eruptive history and hazards. J Volcanol Geotherm Res 91(1):1-21

Hall ML, Steele AL, Mothes P, Ruiz MC (2013) Pyroclastic density currents (PDC) of the 16-17 August 2006 eruptions of Tungurahua volcano, Ecuador: Geophysical registry and characteristics. J Volcanol Geotherm Res 265:78-93

Haynes K, Barclay J, Pidgeon N (2008) The issue of trust and its influence on risk communication during volcanic crisis. Bull Volcanol 70(5):605-621

Hidalgo S, Battaglia J, Bernard B, Steele A, Arellano S, Galle B (2014) Identifying open and closed system behaviors at Tungurahua volcano (Ecuador) using SO2 and seismo-acoustic measurements. EGU General Assembly, Vienna Austria, Abstract id $1615541 \mathrm{H}$

Iguchi M, Yakiwara H, Tameguir T, Hendrasto M, Hirabayashi J (2008) Mechanism of explosive eruption revealed by geophysical observations at the Sakurajima, Sawanosejima and Semeru volcanoes. J Volocanol Geotherm Res 178:1-9, doi:10.1016/j.jvolgeores.2007.10.010

Kelfoun K, Samaniego P, Palacios P, Barba D (2009) Testing the suitability of frictional behaviour for pyroclastic flow simulation by comparison with a well-constrained eruption at Tungurahua volcano (Ecuador). Bull Volcano 71(9):1057-1075

Kumagai H, Nakano M, Maeda T, Yepes H, Palacios P, Ruiz M, Arrais S, Vaca M, Molina I, Yamashima T (2010) Broadband seismic monitoring of active volcanoes using deterministic and stochastic approaches. J Geophys Res 115:B08303, doi:10.1029/2009JB006889

Lane LR, Tobin GA, Whiteford LM (2003) Volcanic hazard or economic destitution: hard choices for Baños, Ecuador. Environ Haz 5:23-34

Le Pennec J-L, Jaya D, Samaniego P, Ramón P, Moreno S, Egred J, van der Plicht J (2008) The AD 1300-1700 eruptive periods at Tungurahua volcano, Ecuador, revealed by historical narratives, stratigraphy and radio-carbon dating. J Volcanol Geotherm Res 176:70-81

Le Pennec J-L, Ruiz GA, Ramón P, Palacios E, Mothes P, and Yepes H (2011) Impact of tephra falls on Andean communities: the influences of eruption size and weather conditions during the 1999-2001 activity of Tungurahua Volcano Ecuador. J Volcanol Geotherm Res (2011) doi:10.1016/j.jvolgeores.2011.06.011.

Leonard GS, Johnston DM, Williams S, Cole JW, Finnis K, Barnard S, (2005) Impacts and management of recent volcanic eruptions in Ecuador: lessons for New Zealand. Institute of Geological \& Nuclear Sciences, Geological and Nuclear Sciences Science Report 2005/20, 51 p. http://civildefence.govt.nz/ assets/Uploads/publications/GNS-SR2005-20-Ecuador-volcano-impacts.pdf
Morrissey MM, Mastin L (2000) Vulcanian Eruptions. In: Surgurdsson H (ed) Encyclopedia of Volcanoes. Academic Press, San Diego, USA, pp 463-476

Mothes P, Vallance J (2015) Lahars at Cotopaxi and Tungurahua Volcanoes, Ecuador: Highlights from Stratigraphy and Observational Records and Related Downstream Hazards. In: Papale P et al (eds) Volcanic Hazards, Risks and Disasters, Hazards and Disasters Book Series. Elsevier, Amsterdam, Netherlands, pp 142-167

Mothes P, Hall M, Hoblitt R, Newhall C (2004) Caracterización de los flujos piroclásticos producidos por el volcán Tungurahua (Ecuador): evidencia de dichos flujos en la ciudad de Baños. Investigaciones en Geociencias, vol 1. Instituto Geofísico \& Corporación Editora Nacional, Quito, pp 19-27

Ramón P (2010) Análisis Retrospectivo de la Evaluación de la Amenaza, el Monitoreo Volcánico y la Comunicación durante las Erupciones del año 2006 del Volcán Tungurahua. Master 2 SGT PREFALC "CIENCIAS Y GESTION DE LA TIERRA" GEOLOGIA, RIESGOS Y GESTION DEL TERRITORIO, Université Nice Sophia Antipolis, p 113, Instituto Geofísico, Quito

Ruiz M, Lees JM, Johnson JB (2006) Source constraints of Tungurahua volcano explosion events. Bull Volcanol 68:480-490

Ruiz AG, Mothes P, Bustillos J, Jarrin P, Yepes H (2012) Predicting Volumes of Magma Influx in 2011 using Ground Deformation Patterns at Tungurahua Volcano, Ecuador. Cities on Volcanoes7, Abstract, Colima, Mexico

Samaniego P, Le Pennec J-L, Robin C, Hidalgo S (2011) Petrological analysis of the pre-eruptive magmatic process prior to the 2006 explosive eruptions at Tungurahua volcano, Ecuador. J Volcanol Geotherm Res 199:69-84

Steffke AM, Fee D, Garcés M, Harris A (2010) Eruption chronologies, plume heights and eruption styles at Tungurahua volcano: integrating remote sensing techniques and infrasound. J Volcanol Geotherm Res 199:69-84

Stone J, Barclay J, Simmons P, Cole PD, Loughlin SC, Ramón P, Mothes P (2014) Risk reduction through community-based monitoring: the vigías of Tungurahua, Ecuador. J of Applied Volcanology 3(11), doi:10.1186/s13617-014-0011-9.

Sword-Daniels V, Wardman J, Stewart C, Wilson T, Johnston D, Rossetto T (2011) Infrastructure impacts, management and adaptations to eruptions at Volcán Tungurahua, Ecuador, 1999-2010, GNS Science Report 2011/24., p 73

Tobin GA, Whiteford LM (2002) Community resilience and volcano hazard: the eruption of Tungurahua and evacuation of the faldas in Ecuador. Disasters 26(1):28-48

Vergniolle S, Mangan M (2000) Hawaiian and Strombolian eruptions. In: Sigurdsson H (ed) Encyclopedia of Volcanoes. Academic Press, San Diego, USA, pp 447-46

Williams R, Stinton AJ, Sheridan MF (2008) Evaluation of the Titan2D two-phase flow model using an actual event: case study of the 2005 Vazcún Valley Lahar. J Volcanol Geotherm Res 177:760-766

Wright HMN, Cashman KV, Mothes PA, Hall ML, Ruiz AG, Le Pennec J-L (2012) Estimating rates of decompression from textures of erupted ash particles produced by 1999-2006 eruptions of Tungurahua volcano, Ecuador. Geology 40(7):619-622, doi:10.1130/G32948

Yamazaki K, Teraishi M, Ishihara K, Momatsu S, Kato K (2013) Subtle changes in strain prior to sub-Plinian eruptions recorded by vault-housed extensometers during the 2011 activity at Shinmoe-dake, Kirishima volcano, Japan. Earth Planets Space 65:1491-1499

\section{Submit your manuscript to a SpringerOpen ${ }^{\circ}$ journal and benefit from:}

- Convenient online submission

- Rigorous peer review

- Immediate publication on acceptance

- Open access: articles freely available online

- High visibility within the field

- Retaining the copyright to your article

Submit your next manuscript at $>$ springeropen.com 